\title{
PROSPECTS OF A SHARI'AH AUDIT FRAMEWORK FOR ISLAMIC FINANCIAL INSTITUTIONS IN MALAYSIA
}

\author{
Sheila Ainon Yussof ${ }^{*}$
}

\begin{abstract}
The need to be in conformity with religious and ethical principles, or to be Shari ${ }^{\prime}$ ah compliant, is the unique and distinctive feature of Islamic finance which sets it apart from its conventional counterpart. Islamic financial institutions (IFIs) are to be audited not only on financial performances but also on their adherence to Shari $\mathrm{i}$ ah precepts, including broader ethical and moral parameters. Currently there is no proper framework to govern the practice of internal Sharīah auditing in IFls. The recently issued Central Bank of Malaysia's Shar icah Governance Framework (CBM-SGF) has made it compulsory for IFIs to perform a regular internal audit of transactions, operations and information systems particularly at the product implementation stage to ensure a comprehensive compliance with Sharīah. This has posed a challenge to Islamic banks and Takaful companies, to develop their own internal Sharicah audit architecture and to train a new breed of internal auditors in the science and ethics of Shari $\mathrm{i}$ ah audit based on generalised guidelines under the new directive. This paper highlights persistent problems relating to inadequate auditing at the business operations level and prevailing issues in Sharicah audit. Recommendations are made for the industry to adopt a common internal Shari $\bar{c}$ ah audit framework as a move towards standardisation and uniformity of audit practice.
\end{abstract}

\section{Introduction}

Malaysia has a parallel system of banking and insurance with two separate laws and regulations for Islamic finance and conventional systems. Under this dual model system, Islamic institutions offering financial services have to grapple with the challenge of competing with conventional institutions for commercial profits whilst having to distinguish themselves from conventional practices through Islamic ethics and religious precepts. Islamic financial institutions (IFIs) need to continually maintain a balance between securing the confidence of ethically conscious stakeholders who require assurance on the compliance of their products and operations with $\operatorname{Shari}^{\mathrm{c}} a h$ and providing a commercially viable Islamic alternative to investors seeking to diversify their investment portfolio. 
This raises the need to develop an effective internal Sharicah audit mechanism and governance to give the necessary assurance that the products, operations and information systems of IFIs are in fact Shari ${ }^{\circ} a h$ compliant.

The Islamic finance industry in Malaysia is "government-driven" where regulators are reputed to be proactive in its supervisory and oversight role. The new Central Banking Act of Malaysia 2009, for instance, was designed to enhance the Bank's board of directors' role to cover a wider oversight responsibility over risk, audit and governance with a commitment to greater harmonisation of practice. The Shariah Advisory Council (SAC) as part of this central regulatory body is also charged with the responsibility of standardisation ${ }^{1}$ of Shari ${ }^{c} a h$ practices within its jurisdictions through the ex-ante scrutiny and ex-post monitoring of Shari ${ }^{i} a h$ compliance. In 2011, more changes were made by the Central Bank of Malaysia when the enterprise-wide Shari ${ }^{c}$ ah Governance Framework (CBM$\mathrm{SGF})^{2}$ was introduced for implementation by Islamic banks and Takaful (Islamic insurance) companies for effective governance on Shari ${ }^{-} a h$ compliance.

At the industry level, the two-tier structure consisting of a centralised Shari ${ }^{\circ} a h$ advisory body (the Shariah Advisory Council ${ }^{3}$ or SAC) and the internal body of Shari ${ }^{i} a h$ scholars or Shari ah Committee (SC) is instituted to ensure that the overall Islamic financial system in Malaysia operates in accordance with Shari ${ }^{c} a h$ principles. At the operations level, Islamic banks and Takaful companies in Malaysia are legally required to have in place a unique two stage review of Shari ${ }^{c} a h$ compliance through in-house Shari ${ }^{c}$ ah scholars': firstly, to get the initial approval/clearance from a $\operatorname{Shari}^{\mathrm{c}} a h$ committee on the Sharic ah compliance with all its products and instruments (referred to as ex-ante compliance) and secondly, at the second level (or ex-post compliance), to give assurances to stakeholders and consumers that their products, processes and activities are in fact in conformity with the religious/legal verdicts or fatwas of the Shari ${ }^{c} a h$ Committee and the objectives of the Sharīah.

Principle 7 of Section VI of the CBM-SGF clearly states that "there shall be a robust Shariah compliance function, comprising review and audit functions, supported by risk management control process and internal research capacity." Since the implementation of this new framework in 2011, IFIs in Malaysia must have review functions that continuously monitor Shari $a h$ compliance of their operations. They must also have annual Shari ${ }^{\circ} a h$ audits which would provide an independent assessment of compliance with established policies. The senior management is responsible for ensuring that all submissions to the Shari ${ }^{i} a h$ committee are adequately researched and supported by a thorough study of the Shari ${ }^{c} a h$ issues for product structuring and documentation. Shari ${ }^{c} a h$ advisors (as auditors) have a greater responsibility to ensure the implementation of decisions involving Islamic law and to inform the bank of any Shari ${ }^{2} a h$ non- 
compliance issues that need to be addressed. The Board in having an overall Shari ${ }^{c} a h$ oversight of IFIs must recognise the independence of their in-house Shari ${ }^{i} a h$ advisors, although the latter are remunerated by them. In this respect, the role of the IFI's board, the Shari ah Committee, and the management in relation to Shari ${ }^{i} a h$ matters has been enhanced to execute Shari $a h$ compliance, and together with the creation of internal review and audit functions supported by risk management and $S h a r i^{c} a h$ research functions, it is aimed at advancing a Shari ${ }^{c} a h$-based operating environment.

The guidelines provided by the CBM-SGF are intended to tighten Shari ${ }^{\circ} a h$ compliance within Islamic banks and Takaful companies, including strengthening the Shari ${ }^{c} a h$ governance and decision-making process, raising Shart ${ }^{i} a h$ advisers' accountability and independence, and requiring audits on banks and Takaful companies. As IFIs have been given a sufficient timeline to implement the CBMSGF by June 2011, it is safe to presume that by now all Islamic banks and Takaful companies would have organised their audit mechanisms, internal control procedures and oversight personnel to ensure effective Shari $a h$ governance based on the regulators' directives, as failure to do so would constitute noncompliance with CBM's directives. The incentive for IFIs to comply with Shari ${ }^{\circ} a h$ and the robust regulatory requirements under CBM-SGF would be to avoid operational and systemic risks whilst remaining relevant as a viable alternative to conventional banks and Takaful companies.

Across the border within the GCC countries, ${ }^{6}$ the Shari ${ }^{c}$ ah governance model of Bahrain, Kuwait, UAE and Qatar (with the exception of Saudi Arabia and Oman) is based on a "minimalist approach", where the regulatory authorities expect IFIs to have proper Shari $a$ a governance system without specifying the requirements in detail. ${ }^{7}$ This is in contrast with Malaysia, which takes on a "proactive" or regulatory-based approach in strengthening its Shari ${ }^{\circ} a h$ governance framework and hence the requirement by CBM for IFIs in Malaysia to adopt the comprehensive SGF Model, where a greater role is given to internal auditing to ensure the effectiveness and integrity of control procedures and information systems, with competent personnel performing the audit and review. Saudi Arabia is the only GCC country that adopts a passive approach where the existing Shart ${ }^{2} a h$ governance system as practiced by IFIs is not dependent on any legal and supervisory requirements but rather is left to the IFIs as a voluntary initiative - to come up with their own system of self governance or self regulation under indirect influence of the market. ${ }^{8}$

The Al-Rajhi model illustrates the self-regulated approach. The appointment of its Sharic ah board is made by the General Assembly or at the Annual General Meeting of shareholders and not by the Board of Directors. This makes the Shart ${ }^{\top} a h$ board independent of all organs of governance such as the management 
and board of directors. Since there is no standard guideline of Shari ${ }^{\circ} a h$ governance issued by the regulatory authority, the Al-Rajhi has passed its own Shari ${ }^{\circ} a h$ guidelines and procedures known as the Shariah Monitoring Guide and Shariah Control Guidelines to ensure proper monitoring and an implementation system of Sharī'ah rulings, (Zulkifli Hasan, 2010).

Oman as a new entrant in the Islamic finance industry is reported ${ }^{9}$ to be opting for the decentralised or minimalist approach rather than the centralised Malaysian model to ensure Sharicah compliance. There will be no single, commonly accepted Shari ${ }^{i} a h$ board overseeing the industry nor creation of a centralised Shari ${ }^{c}$ ah supervisory board like the SAC of Malaysia. ${ }^{10}$ Each bank will establish its own Shart $^{2} a h$ board, as urged by Central Bank of Oman recently in its Islamic banking circular. As in Malaysia, the standards of the Accounting and Auditing Organisation for Islamic Financial Institutions (AAOIFI) ${ }^{11}$ will be used as guidelines; they will not be made compulsory. It is anticipated that there will be various combinations of standards from international and local standardsetters before a unique model for Islamic banks in Oman is created. Kuwait also uses the AAOIFI's Shari' ah standards as guidelines.

Bahrain, Dubai and Qatar favour the adoption of the AAOIFI Audit and Governance standards. ${ }^{12}$ For instance, in Dubai, section 5.3 of the Islamic Financial Business Module (ISF) ${ }^{13}$ requires its IFIs to conduct internal Shari ${ }^{\bar{c}} a h$ review in accordance with the AAOIFI Governance Standards No. 3, and IFIs must ensure that the internal Sharic ah review is performed by the internal audit function or the compliance function either as part of the existing internal audit or compliance department, or as an independent internal Sharī $a h$ audit department of the IFIs. The challenge faced by IFIs in Malaysia in this respect is whether the internal Shari ah audit should be organised as a stand-alone and independent department, where the industry may seek specific requirements from CBM in an organised manner to regulate the functions and profession of internal auditing based on Shari ah precepts.

\section{Statement of Problem}

Issues that are unsatisfactorily addressed of Shari ${ }^{c} a h$ non-compliance at the expost or product implementation stage are one of many persistent problems faced by IFIs (Abdallah, 1994; Besar, 2009). This is evidenced by the frequency and number of cases that were litigated, showing a deviation from Shari ${ }^{i}$ ah standards and fatwas of the Shariah Committees. ${ }^{14}$ Such non-compliance was attributed to the absence of a proper auditing process or to rarely conducted audits, or to very few institutions undertaking any ex-post Shari ${ }^{c} a h$ compliance process (Abdul Rahim, 2009). The Shariah committee report lacks the depth to provide 
assurance: it is merely an endorsement of compliance and not a robust scrutiny of the effectiveness of internal controls. Because of the lack of a comprehensive and regular auditing process, there were rampant instances of "form over substance" compliance as shown in the competitive and sometimes irresponsible behaviour of certain IFIs, where "Shari ${ }^{c} a h$ compliance" was used merely as a label or marketing gimmick for commercial motives, compromising the ethical and religious standards of Islamic transactions. The above problems show the importance of developing a proper and comprehensive internal Shari ${ }^{c}$ ah audit framework for IFIs and for CBM to provide a common internal Shari ${ }^{c} a h$ audit framework for Islamic banks and Takaful companies separately for consistency of practice.

\section{Significance of Shariah Audit and the Central Bank Of Malaysia's Guidelines under the Shariah Governance Framework (Cbm-Sgf)}

As Shari ${ }^{c} a h$ audit is still in its infancy, it has to be understood first from the CBM's perspectives and long-term objectives, as covered under the CBM-SGF. Before defining Shari ${ }^{c} a h$ audit, it is important to know the meaning of Shari ${ }^{c} a h$ compliance and the need for IFIs to comply with Shari ${ }^{\circ} a h$ in order to appreciate the significance of undertaking a religious or Islamic audit. According to the World Bank Policy Research Paper, "conducting activities in accordance with Shari $\bar{i}^{c} a h$ entails that the institution pledges: (i) not to engage in interest-based debt transactions; (ii) not to conduct pure financial transactions disconnected from real economic activity; (iii) not to participate in transactions where there is exploitation of any party, and (iv) not to participate in activities regarded as harmful to society." "Sharicah is defined here as Islamic law extracted from the Qur' an and Sunnah and Ijma' (consensus decision). Research findings also show that the majority of respondents want a more comprehensive view of Shari ${ }^{2} a h$ in line with the need for public accountability of larger institutions. ${ }^{16}$

As a relatively new discipline, there was no widely accepted definition as to what Shari'ah audit really means. The words "review" and "audit" were used interchangeably, causing confusion in the industry as to what standard is to be used for each level of assurance. To overcome the diversity in meanings, a distinction was made by the CBM-SGF on the Shart ah review function, which refers to a "regular assessment on $\operatorname{Sharl}^{2} a h$ compliance in the activities and operations of the IFI by qualified Shari'ah officers, with the objective of ensuring that the activities and operations carried out by the IFIs do not contravene the Shari $a{ }^{\circ}{ }^{\prime \prime} .{ }^{17}$ The Shari' ah audit function on the other hand involves "the periodical assessment conducted from time to time, to provide an independent assessment and objective assurance designed to add value and improve the degree of compliance in relation 
to the IFIs business operations, with the main objective of ensuring a sound and effective internal control system for Shari ah compliance". This distinction helped to bring about clarity and consistency in the definitions and the distinctive roles to be played by reviewers and auditors.

The CBM-SGF further elaborates that the function shall be performed by internal auditors ${ }^{18}$ who may engage the expertise of IFI's Shari'ah officers in performing the audit, "as long as the objectivity of the audit is not compromised". It can be inferred here that internal auditors' consultation with Shari ${ }^{\bar{c}} a h$ department is permissible in the interim Shari ${ }^{c} a h$ compliance period before a fuller compliance is achieved in all areas. What is anticipated to be the strategy of CBM is that as internal Shart $a h$ audit progresses towards a greater uniformity in audit practice and governed by a centralised regulation of the professional practice, a new breed of Islamic auditors will facilitate the advancement towards the regulator's envisioned standard of a Shari ${ }^{\circ}$ ah -based operating environment. This will complete the process of institutionalisation of Shari $a h$ within IFIs as envisaged by ISRA (Akram Laldin, 2009). ${ }^{19}$

On the scope of Shart ${ }^{\circ} a h$ audit, the CBM-SGF guidelines provide an extensive coverage to encompass all aspects of the IFIs business operations and activities, including (1) audit of financial statements of the IFIs; (2) compliance audit on organisational structure, people, process and information technology application systems; and (3) review of the adequacy of the Shari ${ }^{c} a h$ governance process. It is now compulsory for Islamic financial institutions to ensure Shart ${ }^{c} a h$ compliance at all stages of its business activities: from product development, documentation, operations, human resource development to a transparent and technologyenabled information systems including IT, which will prepare the ground for a robust internal Sharī ah audit.

To complete the end-to-end compliance, what should also be reviewed is a dispute-resolution mechanism that can assure customers of the enforceability of Islamic finance contracts in any jurisdiction, as Sharicah law must be the governing law to settle disputes that revolve around Islamic law and ethics.

\section{How is Shariah Audit different from Conventional Audit?}

Shari ${ }^{\circ} a h$ compliance audit is different from a conventional audit as the former is intended to be very broad and includes ethics, religious requirements (ibadah) and the science of business transactions (fiqh muamalat), (Shahul, 2009). ${ }^{20}$ It was argued that the role of the conventional auditor in a capitalist framework is one that is solely accountable to the management and shareholders of the company focusing on financial matters, whilst the role of the auditor in an Islamic economy is wider, as $S h a r i^{c} a h$ auditors are responsible to the society at large and 
are required to uphold Islamic principles (Khan, 1985). This may be so in theory: studies conducted by Nawal (2009) show a gap existing between the "desirable" and the "current" practice of Shari"ah auditing in the IFIs of Malaysia. It will be one of the concerns of this study to highlight the reasons for inadequate auditing at the ex-post stage (the "functional gaps") and the flaws in the existing internal audit system to perform Shari $^{2}$ ah audit.

The other significant difference is that $\operatorname{Shari}^{\mathrm{c}}$ ah auditors and internal reviewers have an added layer of religious accountability, and while assessing the Sharic $a h$ adherence of an entity's financial statements, they are additionally expected to carry out their main religious responsibility of "amr bil ma'ruf wa nahi 'an almunkar" (enjoining the proper and forbidding the improper). This means that all audit dimensions or parameters designed to evaluate Shari ${ }^{2} a h$ compliance must have the spiritual ingredient of God consciousness, that is, a fear of sanctions in the hereafter for not complying with Shari ${ }^{i} a h$. Due to the religious requirements prescribed for Muslims under Shari'ah law implicit in the objectives of the Shari ${ }^{c} a h$, it can be inferred that to undertake the role of religious audit, the auditors and reviewers are required to be Muslims, in order to give the certification on permissible (halal) financing. This is comparable to issuing of halal certification by relevant religious authorities for food and pharmaceuticals, and of religious edicts/decrees (fatwas) of Shari ${ }^{c} a h$ advisors, who likewise must first of all be Muslims. The system of auditing and accounting can be referred to the practices in the early Islamic era where hisba, meaning "to account", "to compute" and "to measure," was expected to be carried out by a group of supervisors known as muhtasib who were appointed to ascertain whether the operation of the market or bazaars complied with the Shari $a h$ principles (Mirakhor, 2000).

Thus Shari $a h$ audit, at least theoretically and until the discipline has fully evolved, is different from conventional audit as the former not only involves a systematic process of obtaining sufficient and appropriate evidence but also evaluates whether the wider dimensions of social, economic, religious, environmental and ethical objectives are met by Islamic financial institutions. In conventional auditing, criteria used to assess compliance are restricted to giving an opinion on the truth and fairness or veracity of the financial statements of corporations, to discover the maximum profits for shareholders. Such a narrow focus was proven insufficient to detect the unethical practices of creative auditing in corporate scandals such as in the case of Enron, which might not have slipped under the radar if the criteria were expanded to include other dimensions instead of just GAAP. ${ }^{21}$

The table below is a summary of the differences between Islamic Auditing and Conventional Auditing as viewed from each of the five dimensions/elements: 
Table 1 Comparison Table between Islamic Auditing and Conventional Auditing 22

\begin{tabular}{lll}
\hline Element & Conventional Audit & Islamic Audit \\
\hline $\begin{array}{l}3 \text { party } \\
\text { relationship }\end{array}$ & Entity, auditor, user & $\begin{array}{l}\text { Entity, auditor and broader } \\
\text { range of users }\end{array}$ \\
$\begin{array}{l}\text { Appropriate } \\
\text { subject-matter }\end{array}$ & $\begin{array}{l}\text { Financial statement assertions: } \\
\text { "opinion on the truth and } \\
\text { fairness of financial statements }\end{array}$ & $\begin{array}{l}\text { Non-financial Statements } \\
\text { (Processes, contracts, } \\
\text { personnel, systems, } \\
\text { performance) and financial } \\
\text { statements }\end{array}$ \\
$\begin{array}{l}\text { Suitable } \\
\text { criteria }\end{array}$ & $\begin{array}{l}\text { International Financial } \\
\text { Reporting Standards (IFRS) }\end{array}$ & $\begin{array}{l}\text { Sharicah principles and } \\
\text { rules, AAOIFI standards and } \\
\text { appropriate parts of IFRS }\end{array}$ \\
$\begin{array}{l}\text { Sufficient } \\
\text { appropriate } \\
\text { evidence }\end{array}$ & $\begin{array}{l}\text { Documented evidence obtained } \\
\text { through observations, vouching } \\
\text { and verification of documents }\end{array}$ & $\begin{array}{l}\text { SSB rulings, fatwas of } \\
\text { international and national } \\
\text { fiqh boards, plus all other } \\
\text { conventional } \text { evidence }\end{array}$ \\
$\begin{array}{l}\text { Written } \\
\text { assurance } \\
\text { report }\end{array}$ & $\begin{array}{l}\text { Standard audit report prepared } \\
\text { by auditor }\end{array}$ & $\begin{array}{l}\text { A more detailed report } \\
\text { prepared by a Sharicah } \\
\text { auditor }\end{array}$ \\
\hline
\end{tabular}

\section{Why Internal Shariah Auditing is important}

The internal audit function is said to be one of the fundamental checks and balances for sound corporate governance. According to the Institute of Internal Auditing Incorporate (IIA Inc.), internal auditing is an independent, objective assurance and consulting activity designed to add value and improve an organisation's operations. In other words, "an internal auditing activity is meant to provide assurance that existing organisational controls are adequate in order to mitigate risks, confirm that governance processes are efficient and effective, and ensure organisational objectives are accomplished" (Ruin, 2011). In a similar manner, the function of $\operatorname{Shari}^{c} a h$ audit as defined by CBM-SGF is to provide independent assessment and objective assurance, designed to add value and improve IFIs compliance with Shari $a h$. It also follows internationally recognised audit standards, objectives and methodology. The Shari ${ }^{c} a h$ audit agenda is however extended to include the promotion of effective Sharitah governance. CBM-SGF also requires $S_{h a r i c}$ ah audit to check for sound and effective internal control for Shari ${ }^{c} a h$ compliance. Currently the industry is focusing only on the existing internal control system sourced from conventional practices, and there 
is a need to have $\operatorname{Shari}^{2} a h$-specific guidelines to measure the internal control system for Shari ${ }^{c} a h$ compliance. ${ }^{23}$ The definition for Internal Control for Sharitah compliance should also be clearly defined. ${ }^{24}$

The recent issuance of the CBM-SGF shows the regulator's increased reliance on internal audit functions as an integral component to ensure effective Sharit $a h$ governance. This raised awareness of the benefits of establishing effective internal audit functions can be attributed to the lessons learned from past global corporate scandals and failures where there was no robust scrutiny of risk management, internal controls and corporate governance. It was also to rectify the problems identified by Sharicah scholars in Malaysia, namely the "absence, or improper and inadequate auditing" at the product implementation (or ex-post) stage. As a consequence, and given that the Islamic finance industry in Malaysia is centrally regulated, IFIs are now directed under the SGF to perform a regular internal audit of transactions, documentations and operations to ensure end-to-end (ex-ante and ex-post) compliance with the Shari ${ }^{c} a h$.

However, guidelines on Sharitah audit under CBM-SGF have been either too general or insufficiently Shari ${ }^{c} a h$-specific or industry-relevant. To address this issue, parallel studies have been undertaken: one, a CBM-initiated study to develop an internal Shari ${ }^{c} a h$ audit framework which will adopt a systematic and disciplined approach in auditing (technical audit); second, research undertaken by this writer to complement the first study by incorporating additional parameters/ benchmark for IFIs to undertake an ethical and maqasid-based audit, to achieve social justice and equitable distribution of wealth, and to balance out the biased focus on commercial profits. Both studies are supportive of the CBM-SGF goal in moving towards a Shari ${ }^{2} a h$-based operating environment, facilitated by a common internal Sharì ah audit framework.

It is yet to be seen whether CBM's study will develop an industry-relevant Shari ${ }^{c} a h$ audit framework, where a specific internal Shari $a h$ audit framework will be structured separately for Islamic banks and Takaful companies. If this initiative is to be undertaken by CBM, it will be a challenge, as Islamic banks and Takaful companies have their own unique operational specificities that cannot be easily translated into a common and uniform approach unless customised options are allowed for greater flexibility and without micro-managing the industry or restricting creativity and innovation. On the other hand, if it is left to the IFIs to develop their own internal audit architecture and practice, it could prove to be a formidable task for IFIs in terms of cost, time and scarce expertise on Shari ${ }^{-} a h$ auditing. As the existing body of knowledge on Shari ah audit is limited, there will be a host of other problems such as the need to ensure consistency and universality in the meaning and application or interpretation of Shari ${ }^{c} a h$ audit, which can only be undertaken by $\mathrm{CBM}$ as the central regulator. Besides, it 
will be difficult for IFIs to develop their own internal audit programmes in the absence of a common template or a prototype Sharit $a h$ model for them to adopt and customise. Allowing Islamic banks and Takaful companies to develop and customise their very own internal Shari ah audit framework could stand in the way of CBM's long term objectives on standardisation and desired uniformity in practice with its manifold benefits.

The CBM's progression towards an integrated approach is anticipated as it is critical to the desired goal of the central regulatory body to have greater uniformity in audit, risk and governance practices as seen in the roles that the governance bodies are designated to play: the CBM's Board of Directors under the Central Bank Act of Malaysia (2009) has a wider oversight responsibility over Risk, Audit and Governance and a commitment to greater harmonisation of practice; the Shariah Advisory Council as part of this central regulatory body is charged with the responsibility of standardisation of Shari ${ }^{\circ}$ ah practices within their jurisdictions through the ex-ante and ex-post monitoring of Shari ${ }^{\circ} a h$ compliance; and the CBM-SGF is directing IFIs to advance towards a Shari ${ }^{c} a h$ -based operating environment.

Diagram 1 below is an illustration of the review and audit functions ${ }^{25}$ from approval stage to implementation stage, and the processes involved in the ex-ante and ex-post monitoring of $\operatorname{Shari}^{i} a h$ compliance by Sharīah advisors, Sharīa $a h$ reviewers and internal $\operatorname{Sharī}^{\mathrm{c}} a h$ auditors:

Diagram 1 Review and Audit Mechanisms to Ensure Shari ah Compliance

By Shariah Committee (SC)

*Ex-ante Shariah compliance review

New Products Approval

*Ex-ante Shariah compliance audit
By Internal Shariah Reviewers and Auditors

${ }^{\star}$ Ex-post Shariah compliance review

\begin{tabular}{|l|l|c|}
\hline Governance & Operations & $\begin{array}{c}\text { Information } \\
\text { Systems }\end{array}$ \\
\hline
\end{tabular}

${ }^{*}$ Ex-post Shariah compliance audit

APPROVAL STAGE

IMPLEMENTATION STAGE

\section{a. Ex-Post Sharī $a h$ Compliance Review}

The function of ex-post monitoring of Shari ah compliance, at the implementation stage, is normally within the exclusive competence of Sharic ah review units in IFIs. In an internal Shari ${ }^{i} a h$ review exercise, two core steps are identified to 
be the best practices of a Shari ${ }^{\circ} a h$ review which require independence from one another to prevent self-reviews: the initial Shari ah setup and the periodic Sharīa ah review.

\section{i. The initial $\operatorname{Shari}^{\mathrm{c}} a h$ set-up}

The initial Sharicah setup is predominantly a legal exercise in which documentation is examined by scholars, lawyers and industry practitioners: Shari ${ }^{c} a h$ compliance is stipulated in the legal context through documentation, internally in the articles of association and externally in the prospectus or offering document; Shari'ah investment guidelines are developed in relation to the funds, the objectives and mechanics to be adopted and crucially the internal compliance function; a Sharī $a h$ compliance manual is drafted which addresses steps, resolutions, non-compliance events, purification of nonpermissible income and formation of the Shari ${ }^{c} a h$ board which issues a fatwa for the product/service being considered. ${ }^{26}$

\section{ii. The periodic Shari ${ }^{\circ} a h$ review}

The internal periodic Sharī ah review is equally important as it is claimed to solidify compliance, or, effectively manage Sharit $a h$ risks of the product/ service as a going concern. This relates to the compliance function, proactive measures to manage $S h a r i^{c} a h$ risks, problem/dispute resolution, and continuous guidance of the Shari ${ }^{c} a h$ supervisory board whilst preparing the grounds for future development of an external Shari $a h$ audit regime. ${ }^{27}$

The Shari $a h$ review function under CBM-SGF refers to regular assessment on Shari $a h$ compliance in the activities and operations of the IFIs by qualified Shari ${ }^{2} a h$ officers. The function involves the examination and evaluation of the IFIs' level of compliance to Shari' $a h$, remedial rectification measures to resolve non-compliances, and control mechanism to avoid recurrences.

\section{b. Ex-Post Shariª ah Compliance Audit}

An IFI will require two types of audit:

i. Internal $\operatorname{Shari}^{\mathrm{c}} a h$ audit, which can be carried out by the existing internal auditor or compliance officer who must have the requisite knowledge of Islamic banking principles and fiqh muamalat, and

ii. External Sharīah audit, which can be supported by an audit firm with Islamic finance expertise such as Deloitte, Price Water House.

The current framework adopted by IFIs follows standards stipulated by the International Standards for Professional Practice of Internal Auditing (IPPF) 
issued by the Institute of Internal Audit (IIA) and Guidelines on Minimum Audit Standards for Internal Auditor of Financial Institutions issued by CBM. ${ }^{28}$ As CBM has given the responsibility to perform Sharic ah audit to the internal audit department, this will invariably expand the traditional job scope of internal auditors to include Islamic or religious and ethical auditing. Thus the existing internal audit department will not only act as a key organ of corporate governance where auditors also provide internal consultancy, but now it will have to perform Shari ah audit to ensure that the operations of the IFIs are Shari ${ }^{c}$ ah compliant. The challenge faced by the CBM is whether the existing leveraging on the Group's (the parent company's) internal audit programme will be effective in ensuring $\operatorname{Sharl}^{i} a h$ governance. The majority of respondents from a recent study indicated, however, that there is a need for a general framework that can be used by IFIs to standardise the practices of Shari ${ }^{c} a h$ auditing among IFIs. ${ }^{29}$ This could mean that internal Shari ${ }^{c} a h$ audit must be developed as a structured and single framework, separate from the Group, specifically for subsidiaries of a conventional Islamic bank. With increased accountability of internal Shari ${ }^{c} a h$ auditors, it will necessitate a comprehensive training programme to ensure that they are qualified and competent to undertake the new multidisciplinary role as internal Shari ${ }^{c} a h$ auditors, possessing both audit and Sharic ah qualifications (usul al-fiqh or fiqh muamalat), so as to boost public confidence and give objective assurances of the integrity of the Shari ${ }^{c} a h$ audit profession.

An internal audit cycle or methodology usually involves three different stages commencing with the (1) Planning (of audit exercise) phase; (2) Examination (of evidence) phase, and the (3) Reporting phase (for full disclosure of information or transparency and accountability) and the remedial actions required to be taken by IFIs before the annual audit by external auditors. Based on an interview of an Islamic bank (hereinafter Bank X), the audit process of an internal Shari ${ }^{c} a h$ audit may be illustrated as follows: ${ }^{30}$

1. Ensure that products, operations and documentations of Bank $X$ are compliant with internal Shari ${ }^{-} a h$ ruling as prescribed by internal Shari $a h$ Review and external Shari ${ }^{c} a h$ principles such as those of BNM and SC and where applicable, international standards such as AAOIFI and IFSB ${ }^{31}$;

2. Ascertain whether Bank X's system of internal controls and related policies and procedures to mitigate the identified Shari ah compliance risk areas were executed satisfactorily throughout the audit period under review;

3. Ensure that adequate and knowledgeable personnel are managing the dayto-day business and operations functionalities at Bank X. 
To satisfy the principles of good governance, Shari ${ }^{c} a h$ audit shall report directly to the Board Audit Committee for independence and objectivity in order to avoid any conflict of interest and undue influence from management whilst carrying out its function of providing independent assessment and objective assurance to stakeholders designed to add value and improve the organisation's compliance with Sharī ah.

\section{Prevailing Issues in Shariah Audit}

\section{a. Narrow Scope of Shari $a h$ Audit being Practiced}

It is observed that concerns raised by scholars and academicians in applying a narrow view of Shari ${ }^{c} a h$ compliance are being overlooked by the CBM-SGF, for whom compliance is still "a compliance to Shari" ah rulings and decisions issued by the SAC and Shariah Committee of the IFI respectively, and as determined by other relevant bodies". The focus continues to be restricted to technical or legal (fiqhi) compliance, unless CBM is planning to direct industry players to apply the golden rule ${ }^{32}$ or the wholesomeness (tayyib) principles, ${ }^{33}$ in interpreting or construing documents or processes to impute lawful and good or socially relevant intentions. Such an application will be logistically impossible to supervise, unless there is a common tool specifically designed for the industry to measure both the lawful and goodness/wholesome aspects of Sharic ah compliance through a broader and deeper maqasid-based audit.

The dangers of measuring Sharl'ah compliance "in form only" have been highlighted by scholars in this area (Yusuf Saleem, 2012), where it is important that the legal validity of transactions must be enhanced by realisation of the maqasid of public good (Hashim Kamali, 2008). Saiful Azhar Rosly (2006) (4) $^{34}$ recommends a multidimensional approach in determining the legality of Shari ${ }^{\circ} a h$ compliant instruments "on a wider scale of measurement" to include other parameters such as aqd, legal documentation of contract, accounting \& financial reporting, and a maqasid approach.

By expanding the audit parameters to allow a multifocal audit, the whole gamut of business activities (as audit deliverables) can indeed be evaluated on a wider scale of measurement. But if the auditing is performed to assure stakeholders of the legality of transactions and processes without looking at the maqasid of public benefit, or where the business deal is causing harm to the individual and community, then it will not serve the Shari ${ }^{i} a h$ principles of social justice and fair dealing. Ethical and religious requirements of justice and fair dealings and equitable distribution of wealth cannot be downplayed as Shari ${ }^{2} a h$ is based on promotion of human welfare and social justice. Consumers have the right to know whether transactions are placing them at a disadvantage or where 
they can be exploited or oppressed by IFIs. If such pertinent information is not revealed to consumers in, for example, promotional materials or annual Shari ${ }^{\circ} a h$ committee reports, then internal auditors would have failed in their ethical and religious duty of disclosure. Stakeholders need full information on any unethical practices or risks of non-compliance for them to make a well-informed decision on choice of IFIs, products and transactions and investments. Thus, widening the scope of audit does not mean only expanding the audit parameters or creating a multidimensional technical/legal benchmark. It must also fulfil the Sharī $a h$ objectives of justice, equity and fair play, and good conscience. Internal auditors must be trained to assess IFIs compliance with objectives of Shari ah (maqasid al-Sharl $\left.{ }^{i} a h\right)$, to complement their technical expertise on auditing.

One can attribute the lop-sided or unbalanced approach in assessing or assuring Sharic $a h$ compliance to the fact that there is no structured methodology to measure universal principles of justice, equity, fair dealings and compassion or good conscience. The examination of evidence of deviations from Shari ${ }^{\circ} a h$ principles can only be made after the fact, where there is a clear violation of consumers' rights and an increasing number of product liability suits against Islamic financial institutions. For IFIs to embark on a common mission to ensure company-wide Sharicah compliance, a Shari ${ }^{i} a h$-specific Audit Charter should be developed to reflect the Shari'ah mission and the organisation's vision in an integrated and holistic manner. By incorporating a common vision and proactive Shari ${ }^{c} a h$ audit programme, the infusion of religious values can be made throughout the audit plan in the form of a Vision-Mission-Goal (VMG): the audit objectives, scope of auditing, the authority and mandate of auditors, and the objectivity, professionalism and independence required of internal Shari ${ }^{\circ} a h$ auditors. It is hoped that a restricted view on Shari ${ }^{i} a h$ compliance will not be applied in any proposed internal Shari ${ }^{c} a h$ audit framework, but that a balanced, integrated and holistic auditing will instead be adopted where the audit practice will look at both technical and ethical auditing to ensure Shari ${ }^{c} a h$ compliance in form and substance.

\section{b. Lack of an Organised Internal Shari ${ }^{c}$ ah Audit Framework}

Most IFIs are using the conventional framework of auditing because of the current unavailability of an organised Sharīah -specific internal auditing framework, even though the majority of respondents recognised that there is a need for Shari ${ }^{c} a h$ auditing to be different from the conventional framework (Nawal, 2009). In a study on the role of internal auditing in ensuring governance in IFIs, the findings indicated that IFIs are still struggling to establish an effective Shart ${ }^{\circ} a h$ auditing framework (Yahkiruni and Nurmazilah, 2012). It can be inferred from these studies that due to the lack of a structured Sharitah auditing framework, 
the practice of Shari $^{\mathrm{c}}$ ah audit has not made a serious impact on IFIs of Malaysia. The existing internal audit structures in banks and Takaful companies are either leveraged on the Group Internal Audit (based on conventional audit framework with modification) or outsourced to professional Shart $a$ a compliant auditing firms. The current framework used by a majority of IFIs is a shared model but with certain modifications, and the respondents in that study indicated the need to have one general framework that can be used to standardise the practices of Shari ${ }^{\bar{c}}$ ah auditing among IFIs. ${ }^{35}$ As such the internal audit units are not organised to exist as a stand-alone or independent function to undertake Shari ${ }^{-} a h$ audit, and may lack cohesion or are too fragmented for a comprehensive audit to be undertaken on Shari ${ }^{c} a h$ compliance.

As internal Sharicah auditing is considered to be an integral component of the Shari'ah Governance Framework, what is urgently needed by the industry is a comprehensive framework which can provide specific guidelines, through a common audit architecture and mechanics, to properly and effectively conduct Sharī ah audit. CBM has given this task to the International Shariah Research Academy for Islamic Finance (ISRA) to develop the Internal Sharī $a h$ Audit Framework (ISAF) for IFIs. The Exposure Draft has been circulated to the industry since July 2012 for their on-going comments and suggestions for improvements on the proposed framework. To complement the CBM's ISAF initiative, a study undertaken by this writer as part of a larger study on internal Shari ${ }^{c} a h$ audit in Malaysia will expand the audit parameters to include the ethical and moral dimensions and for IFIs to progress towards a maqasid-based audit. ${ }^{36}$ The writer's proposed Shari $a h$ model will assess whether IFIs are ethically responsible and conscious of their role as trustees to ensure social justice through an equitable distribution of wealth in the offering of financial services to the community.

\section{c. Shortage of Qualified Internal Sharĩ ah Auditing Personnel}

In Malaysia, the CBM-SGF has specified that Shari ${ }^{\circ} a h$ audit should be conducted by internal auditors from the internal audit department. The internal auditor should be competent in terms of Shari ah knowledge and understanding on the Shari ${ }^{c} a h$ issues related to products and operations Generally, the professionals involved in an internal Sharicah audit programme are the Shari $a h$ committee member (as auditors) and the internal Shari ${ }^{i} a h$ auditors. ${ }^{37}$ The internal Shari ${ }^{c} a h$ auditors should be directly accountable to the Board Audit Committee. The role of the Shari ${ }^{\circ}$ ah Committee (as collective in house religious advisors and auditors) covers five main areas: (i) Certifying permissible financial instruments through fatwas (ex-ante Sharicah audit); (ii) Verifying that transactions comply with issued fatwas (ex-post Sharicah audit); (iii) Calculating and paying zakat; (iv) 
Disposing of non-Shart ${ }^{c} a h$ compliant earnings; and (v) Advising on the distribution of income or expenses among shareholders and investment account holders.

Because of the unique role that they are called upon to fulfil, Shari ${ }^{2}$ ah Committee members and internal Shart ${ }^{c} a$ auditors should ideally be knowledgeable in Islamic law and commercial transactions and accounting/auditing practices. But the scarcity of professionals with combined Shari ${ }^{c} a h$ knowledge and financial audit skills hampers industry efforts to have an effective Shari' $a h$ audit. Very few people are well versed in both disciplines. A similar constraint also applies to conventional finance industry internal auditors who are now required to have a multidisciplinary background and to be multidimensional and multifocal in the audit exercise. People with such a combination of skills and expertise constitute a rare breed, without even considering adding Shari $a h$ knowledge to the required qualifications.

The CBM-SGF ${ }^{38}$ has ambitiously raised the entry point for prospective members of the Shari ${ }^{c} a h$ Committee at a time when there is already a dearth of experts or scholars, vis "the Shari"ah Committee is expected to have sufficient knowledge on finance in general and Islamic finance in particular to enable the members to comprehend Sharīah issues brought before them." However this issue is addressed, it means including people from different backgrounds or disciplines as members of the Shari ${ }^{c}$ ah Committee.

Not only are the entry qualifications for $\operatorname{Shari}^{c} a h$ advisors and internal Shari ${ }^{c} a h$ auditors important but also the on-going training and certification of members to enhance their knowledge and understanding of the Shari ${ }^{c} a h$. The current postgraduate and industry-driven courses have been found to be inadequate to equip Shari ${ }^{c} a h$ advisors with the expertise required. A certification programme, like a Masters in Shari ${ }^{i}$ ah Advisory, should be designed to address this issue. With institutionalisation of $\operatorname{Shari}^{2} a h$, it is expected that in the near future only those with the basic entry qualification (a degree in Islamic law or commercial law) and a Masters in Shari ${ }^{i} a h$ Advisory can be called to serve on the Shari ${ }^{c} a h$ supervisory board or Shari ah Committee. A comprehensive training is also required to convert conventionally trained internal auditors to internal Shari ${ }^{i} a h$ auditors.

\section{d. Extreme Brevity of Sharī ah Committee Reports}

The Shari ah Committee Report (SCR), like the auditor's report which serves as an executive summary of the Shari ${ }^{\circ} a h$ compliance aspect of an IFI, is attached to the auditor's report and made accessible to the public as a company's annual report. Abdel Karim (1990) maintains that Sharĩ ah reports assure readers that the financial statements of the bank are in accordance with Shari $a h$, and also state whether the Shari ${ }^{i} a h$ Committee had access to all the documents and records deemed necessary The report generated after an audit exercise is meant 
to give credibility to the information in the financial statements from a religious perspective. Such assurance is to enhance and strengthen the stakeholders' confidence in the Islamic banks' operations. It should be noticed that the stakeholders are quite large and comprise all those with vested interest in the wellbeing of Islamic banks like the employees, customers, suppliers, supervisors, and the Muslim community (ummah) as a whole. ${ }^{39}$

By virtue of the "Guidelines on Financial Reporting for Licensed Islamic Banks" (GP8-i) on Annual Financial reports, the Sharic ah Committee's Report is a mandatory requirement (part 2: Financial Reports Requirements). The CBM's GP8-1 provides a sample, at the minimum, of how a Shari ${ }^{c} a h$ report should be formulated or takes on a particular form (p. 27 of GP8-i). It does not require IFIs to report on how the audit is conducted. It requires only a basic disclosure and transparent reporting.

Although research was undertaken to highlight the issues relating to the extreme brevity of Shari'ah Committee Reports and the need for a more quantitative reporting (Shahul, 2009), the CBM-SGF did not provide a comprehensive reporting template but left it to the industry to define. ${ }^{40}$ The SCR contains only qualitative or subjective opinions of the Shart ah Committee and a statement simply "that the overall operations of the IFI are in compliance with Shari"ah law and regulations".

CBM-SGF requires the findings from an internal Shari ${ }^{c} a h$ audit to be reported to the Board Audit Committee and communicated through the Shari ${ }^{\circ}$ ah Committee Report (SCR). ${ }^{41}$ There is no third party or external auditors' attestation of the statement made by the Shari ah Committee on IFIs conformity with Shari ah. The auditor's report in the annual reports of IFIs is thus basically not a Shari ${ }^{-} a h$ audit report, (Mustafa, Zurina, Supiah and Nurazalia, 2012). This raises concerns as to the objectivity and reliability of both the SCR and the auditor's report, as stakeholders need full disclosure not only on financial statements but also a clear written expression from external auditors that the overall operations of the IFIs are in compliance with Sharicah principles.

The SCR in Malaysia not only suffers from brevity in reporting, but the reporting styles differ from one bank to another and are inconsistent with each other in terms of content, scope and format because of different processes and procedures in place within these banks in instituting Shari ${ }^{2} a h$ audit exercises. ${ }^{42}$ Some banks' auditing processes are too simplistic, which raises transparency and proper governance issues. ${ }^{43}$ It was discovered that SCRs of banks outside Malaysia, where the regulatory authorities in each of these countries have different governance and supervisory requirements, also show a similar inconsistency or lack of uniformity in reporting due to the absence of a comprehensive and common template. ${ }^{44}$ 
e. Dispute Resolution Mechanisms: Inadequate Training of Judges from Mucamalat Bench

It can be inferred from the proliferation of product liability suits against banks in Malaysia that the increasing incidence of deviations from Shari $a h$ rules and principles (especially in the Bai Bithamin Ajil or BBA financing instrument) can be attributed to the functional gaps and the need for robust internal audit architecture. It was shown in the majority of these cases that the $M u^{c}$ amalat bench under the jurisdiction of the Civil High Courts was ill-equipped to decide on Shart ${ }^{c} a h$ matters or Shari $a h$ non-compliant disputes, as judges selected to fill the positions have not undergone training in fiqh mucamalat. However, this issue is resolved through the positioning of the Shariah Advisory Council as the top authority for the determination of Islamic law for the purposes of Islamic finance business. This means that the SAC has the mandate to act as the highest "appellate or review body" to ascertain relevant Islamic law on any financial matter and issue a ruling upon reference made to it. The SAC's other mandate includes advising the Central Bank and the IFI concerned in any Sharic $a h$ issues relating to Islamic financial business operations, activities or transactions. Another route for an expeditious settlement of Islamic finance disputes is through arbitration, which is a better alternative to litigation, which is costly and takes a longer time for the parties to get justice within a civil law-based forum for settlement of disputes. To this end, the Kuala Lumpur Regional Centre for Arbitration (KLRCA) has been offering rules for arbitration of Islamic banking and financial services in the domestic sphere since 2007. Recently, the KLRCA has come up with an adapted set of rules that provide for international commercial arbitration based on Islamic principles which will be recognised and enforced internationally to facilitate cross-border transactions, enhancing the role of Malaysia as an Islamic arbitration centre..$^{45}$

\section{Conclusion and Recommendations}

Although it was desired that a proper and comprehensive internal Shari ${ }^{\circ} a h$ audit programme should be developed to move the industry towards a greater harmonisation of internal audit practices and a Shari ${ }^{c} a h$-based operating environment for IFIs, the CBM-SGF did not provide a prototype internal Shari ${ }^{c} a h$ audit architecture and mechanisms for Islamic banks and Takaful companies to adopt and customise. It was left to the creativity and ingenuity of IFIs to design their own internal audit programme based on CBM's principle-based guidelines with minimum prescriptions on best internal audit practices and standards. ${ }^{46}$ In view of the lacuna, a more prescriptive approach by CBM is preferable. It was also to address those prevailing issues in $\operatorname{Shari}^{\mathrm{c}} a h$ audit that thematic workshops were 
organised by ISRA to brainstorm ideas with industry players, auditors, regulators and Shari ${ }^{c} a h$ scholars on the appropriate framework to be developed for internal Shari ${ }^{c} a h$ audit of Islamic financial institutions in Malaysia. This effort culminated in the drafting of the "Exposure Draft for Internal Shariah Audit Framework" (ISAF) for IFIs in Malaysia in 2012, representing yet another of CBM's proactive initiatives to ensure effective Shari ${ }^{-} a h$ governance. To complement the CBM's effort in this area, the following recommendations are proffered:

- As Sharīah audit is still uncharted territory, it is recommended that the CBM undertake this task, instead of leaving it to the industry, by providing the benchmarks and standards (or the prescriptions) required for an efficient and effective Internal Shariah Audit Framework. The prototype model will be adopted by Islamic banks and Takaful companies with modifications to suit each industry's unique product and operational requirements while making it industry-relevant.

- IFIs in Malaysia should establish an Audit Charter that will be Shart ${ }^{2} a h$ -specific or reflect the Sharī ah "mission" in their organisation's vision of the scope, purpose, authority, accountability and responsibility for the internal Sharīah auditing department. A Sharīah-specific Audit Charter will ensure that internal auditing will be integrated and holistic in its approach through which both the rational and religious science of audit will govern the Internal Shari ${ }^{c}$ ah Auditing Department to advance towards a common and balanced focus as a technical, ethical and maqasid-based audit (Sheila \& Soualhi, 2012).

- A comprehensive Talent Development Programme needs to be designed for internal Shari ${ }^{c} a h$ auditors, Shari $a h$ reviewers and Shari ah advisors for skill training, cross-training or cross fertilisation of ideas between audit and Shari ${ }^{c} a h$, and continuous professional education on Shari ${ }^{c} a h$ audit through professional and certification courses to ensure that auditors, reviewers and advisors are competent, professional and efficient in their audit practice. This will widen the pool of expertise and prevent poaching of internal auditors within the industry.

- A Professional Practice Code for Shari ${ }^{c}$ ah Auditors needs to be developed to govern the profession of auditing (covering internal and external auditors) and ensuring uniformity in audit practice. Internal Shari $a h$ auditors under the new regime will play a wider role not only to act as a key function of corporate governance, but also to perform Sharicah audit to ensure effective Shari ${ }^{c} a h$ governance. A centralised regulation of the practice and profession of Shari ${ }^{2} a h$ audit is required, to prevent stagnation in the development of this nascent discipline. 
- On Audit Reports, IFIs in Malaysia may consider reporting the Shari ${ }^{\circ} a h$ audit findings as a separate statement in their annual report to promote greater transparency in Shari ah compliance. This can be in the form of a Shari ${ }^{c}$ ah Committee Annual Report which is a compilation of all the fatwas, rulings, product approval documentation including a summary of the Sharīah non-compliance risk areas, the risk-based approach in auditing and the proactive remedial measures that are in place to ensure efficiency and efficacy of internal control system. The annual audit reports of external auditors must reflect not only the financial statements, but also the overall operations of the IFIs as well as the extent of the accomplishment of the IFIs' corporate social responsibility not only in charitable activities but in eradicating poverty and instituting social justice and caring for the environment.

To conclude, it is due to the unavailability of a Shari ${ }^{c} a h$-specific internal audit model that current audit practice in the industry continues to replicate the mainstream mechanics of auditing with its shortcomings in terms of the restrictive focus on financial audit, whereas $\operatorname{Shari}^{\mathrm{c}}$ ah audit should have a wider scope to cover not only an audit of financial statements, but also to undertake a compliance audit on organisational structure, people, process and IT application systems, including a review on the adequacy of Shari ${ }^{c} a h$ governance process. ${ }^{47}$

What is required is an internal Shari ${ }^{c} a h$ audit framework that makes an independent assessment and objective assurance of both legal and ethical compliance to Shari ah. The audit programme is to be designed to take into account IFIs' fulfilment of the public benefit/public good requirement and social responsibility. The internal Shari ${ }^{c} a h$ audit framework shall also apply international audit standards on organisational controls ${ }^{48}$ to meet the following objectives: to safeguard organisations' assets, ensure compliance with both internal and external legal, regulatory and $\operatorname{Shari}^{\mathrm{c}} a h$ requirements, ensure integrity (accuracy, timeliness, reliability) of financial data and statements, and to see that the established organisational controls facilitate organisational efficiency, effectiveness and economy of operations.

Through an integrated and holistic approach of the recommended internal Shari ${ }^{\circ} a h$ audit framework, a consistent and reliable assurance can be given to stakeholders on the integrity of IFIs internal control system and staffing and fulfilling its function in ensuring effective Sharic ah governance.

Lastly, a policy issue paper to be written by this writer will recommend to policy makers specific punitive measures to be legislated in order to deter unethical practices and persistent violations of Islamic laws and regulations by IFIs in Malaysia and ensure a sustainable development of the Islamic finance industry in Malaysia. 


\section{Notes}

* Sheila Ainon Yusoff is a Senior Analyst at IAIS where she heads the Policy Issue Papers editorial board. An advocate and solicitor, she now specialises in Islamic finance, and is nearing completion of her doctoral studies in the same area.

1. "Standardised" or "harmonised" Shart"ah concept is a component of institutionalisation of Shari"ah. M. A. Laldin (2010) of ISRA defines institutionalisation of Shari $a$ ah as the process of embedding Shari ${ }^{2}$ ah concept within an organisation which in turn governs the behaviour of a set of individuals in the organisation or outside it. Standardisation of Islamic financial contracts has its major benefit of ensuring the enforceability of such contracts in disputes brought before civil courts that are not legally bound by the Shart ${ }^{2} a h$.

2. Islamic Banking and Takaful Department, "Shart"ah Governance Framework for Islamic Financial Institutions," BNM/RH/GL_012_3. The Framework is issued pursuant to S 59 of the Central Bank of Malaysia Act 2009, S 53A of the Islamic Banking Act 1983; S 69 of the Takaful Act 1984; S 126 of the Banking and Financial Institutions Act (BAFIA) 1989 and S 126 of the Development Financial Institutions Act (DFIA) 2002 (where the two latter institutions are participating in the Islamic Banking Scheme). The Framework is to be read with other related guidelines issued by CBM.

3. The Shariah Advisory Council (SAC) is a body established under section 51 of the Central Bank Act 2009 to be the apex authority for determination of Islamic law for Islamic financial business. The mandates of the SAC are: (1) to ascertain the relevant Islamic law on any financial matter and issue a ruling upon reference made to it; (2) to advise BNM and the IFI concerned on any Shari $\bar{t}^{c} a h$ issues relating to Islamic financial business operations, activities or transactions. BNM/ RH/GL_012_3, p.1

4. The establishment of the Shari ${ }^{\circ}$ ah Committee is a statutory requirement for Islamic banks pursuant to S 3(5)(b) of Islamic Banking Act 1983; for takaful operators pursuant to S 8(3)(a) of Takaful Act 1984; for Islamic Banking Scheme Banks pursuant to S124 (7) of the Banking and Financial Institutions Act 1989 and prescribed under S16B of the Central Bank of Malaysia (Amendment) Act 2003 for Central Bank of Malaysia. Shari $a h$ compliance refers to compliance to Shari ${ }^{i} a h$ rulings and decisions issued by the SAC and Shari ${ }^{2}$ ah Committee of the IFI respectively and as determined by other relevant bodies.

5. Islamic Banking and Takaful Department, "Shariah Governance Framework for Islamic Financial Institutions," BNM/RH/GL-012_3.

6. Countries in the Gulf Co-operation Council (GCC) consist of Bahrain, Kuwait, Oman, Qatar, Saudi Arabia and UAE. With the exception of the Sultanate of Oman, all IFIs in the other GCC countries have their own framework of Shart ${ }^{i} a h$ governance systems, where Zulkifli (2010) classifies the Shari ${ }^{2}$ ah governance approach under two distinct categories: regulation through legal and supervisory requirements as in the case of Bahrain, Kuwait, UAE and Qatar, or through selfregulation as in the case of Saudi Arabia.

7. Zulkifli Hasan, "Regulatory Framework of Shari"ah Governance System in Malaysia, GCC Countries and the UK," Kyoto Bulletin of Islamic Area Studies 3, no. 2 (March 2010), 82-115.

8. Ibid.

9. Reuters, 27 June 2012.

10. Bahrain is the only country in the GCC to establish a National Shariah Advisory Board in the Central Bank of Bahrain to serve and to verify Shart ah compliance but it does not have authority upon the IFIs unlike Malaysia, Sudan, Indonesia, Pakistan and Brunei (Zulkifli, 2010).

11. The Accounting and Auditing Organisation for Islamic Financial Institutions (AAOIFI) is an international standard setter on audit, governance and Shart $a h$ standards, but the standards are not mandatory for IFIs to adopt.

12. To date (2010) international standard setter (AAOIFI) has issued seven governance standards covering: 1.Appointment and composition of Shariah Supervisory Board; 2. Checks and balances brought about through external Shari ${ }^{c} a h$ reviews; 3. Functions of internal Sharitah reviews; 4. Monitoring of Shari ah-compliance by audit and governance committees; 5. Independence of Shart ${ }^{2}$ ah Supervisory Board; 6. General statement on governance principles for IFIs and 7. Corporate Social Responsibility. 
13. IFIs registered under Dubai International Financial Centre have to comply with the DIFC law and regulations particularly the Law Regulating Islamic Financial Business DIFC Law No. 13 of 2004 and the DIFC Services Authority (DFSA) Rulebook on Islamic Financial Business Module (ISF).

14. Reuters (2009); Disputes on the compliance of certain products such as a recent case involving Kuwait's Investment Dar have put the spotlight on the role of Shari ${ }^{\circ} a h$ advisers in approving products and their relationship with bank management. As such, the CBM made it a legal requirement for Islamic banks to set up Sharia review, audit and risk management control functions to reinforce compliance.

15. Wafik Grais and Matteo Pellegrini, "Corporate Governance and Shariah Compliance in Institutions Offering Islamic Financial Services", World Bank Policy Research Working Paper 4054 (November 2006), available online at http://econ.worldbank.org (accessed on 30 August 2009).

16. Shahul Hameed and Ratna Mulyani, "Shariah Audit for Islamic Financial Institutions: Perceptions of Accounting Academicians, Audit Practitioners and Shariah Scholars". This research won the Third Malaysian Outstanding Research Paper Award 2009 under the Audit Category. Some of the research findings were used in this paper to justify changes on the flawed auditing system in Malaysia.

17. Islamic Banking and Takaful Department, "Shariah Governance Framework for Islamic Financial Institutions," BNM/RH/GL-012_3, Section VI: 'Shariah Compliance \& Research Functions'. The Shart ${ }^{i} a h$ officers must hold at least a bachelor's degree in Shari ${ }^{i} a h$ which includes study in the origins of Islamic law (Usul al-figh) and Islamic commercial transactions (figh muamalat).

18. Internal auditors must acquire adequate $S h a r i^{c} a h$-related knowledge and training.

19. Where institutionalisation of Shari $a h$ is defined as the process of embedding Sharitah concept within an organisation which in turn governs the behaviour of a set of individuals in the organisation or outside it.

20. Shahul Hameed Mohd Ibrahim, "The Case for Islamic Auditing", International Accountant Journal (January 2009), available online at http://www.kantakji.com/fiqh/Files/Accountancy/v181.pdf.

21. Generally Accepted Accounting Principles (GAAP) is a term used to refer to the standard framework of guidelines for financial accounting used in any given jurisdiction, generally known as Accounting Standards. GAAP includes the standards, conventions, and rules accountants follow in recording and summarising transactions, and in the preparation of financial statements.

22. Shahul Hameed Mohd Ibrahim, Accounting and Auditing for Islamic Financial Institutions (Kuala Lumpur: INCEIF, 2009), 417.

23. Hajah Mustafa Mohd Hanefah, Zurina Shafii, Supiah Salleh and Nurazalia Zakaria, Governance and Shariah Audit in Islamic Financial Institutions (Negeri Sembilan: Universiti Sains Islam Malaysia, 2012), 167.

24. Ibid.

25. The diagram is a graphic illustration of internal audit control process/system for IFIs by the writer.

26. "The Shariah Compliance Toolkit", Opalesque Islamic Finance Intelligence (July 2009), Editor's Note, 3 .

27. Ibid.

28. Based on research findings undertaken to investigate how the approach or process has been adopted by the internal audit department in relation to the framework or standards, audit process, audit programme and plan.

29. Yazkhiruni Yahya and Nurmazilah Mahzan, "The Role of Internal Auditing in Ensuring Governance in IFIs", Proceedings of the $16^{\text {th }}$ International Business Information Management Association Conference (Kuala Lumpur: 2012).

30. Extracted from the audit objectives of a local bank which is an Islamic subsidiary of a parent conventional bank.

31. The International Financial Services Board (IFSB) is an international standard setter based in Malaysia established for the purpose of providing prudential governance standards for IFIs.

32. The Golden Rule of statutory interpretation may be applied where an application of the literal rule would lead to an absurdity. English courts have appealed to this Rule as, among other things, a benchmark of good advocacy, a means of determining whether a claimant deserves an equitable remedy, as the basis for principles of equitable fair dealing, restitution of unjust enrichment and other purposes to give a more just result. 
33. Tayyib principles focus on the spirit and purposes (maqasid) of Shari ${ }^{i} a h$. There are verses from the Quran mentioning "Tayyib": Surah Al-Maida, "Eat that which Allah hath bestowed on you as food lawful and good, and keep your duty to Allah in Whom ye are believers". Thus not only should Islamic finance structures be lawful, but it must be "wholesome" or "good", being more beneficial than basic halal options.

34. Saiful Azhar Rosly, "Shariah Compliant Parameters Reconsidered," paper presented at the Annual Malaysian Finance Association Conference, in Kuching, Malaysia, on 4-5 June 2008.

35. Yazkhiruni and Nurmazilah, "The Role of Internal Auditing," Appendix 1: "The Structured Interviews Data Matrix’.

36. See Sheila Ainon Yussof and Younes Soualhi, "The Maqasid Filter in Takaful Audit”, in: Islamic Banking and Finance: Principles, Instruments and Operations (Selangor: The Malaysian Current Law Journal Sdn. Bhd.), 699-714.

37. A qualified Shari ah Reviewer/Officer holds at least a bachelor's degree in Shari $a$ ah, which includes study in Usul al-Fiqh and Fiqh Muamalat.

38. Central Bank of Malaysia Sharĩ ah Governance Framework (2011), Section IV: Competency, Principle 4: "Any person bearing responsibilities outlined in the Shari"ah governance framework for an IFI shall possess the necessary competency and continuously enhance their knowledge and understanding on the Shari $a h$ as well as keep abreast on the latest developments in Islamic finance." See "Shariah Governance Framework for Islamic Financial Institutions," BNM/RH/_012_3.

39. Karim Abdel Karim, R.A. (1990), "The Independence of Religious and External Auditors: The Case of Islamic Banks," Accounting, Auditing \& Accountability Journal 3, no. 3 (March 1990), 34-44.

40. "Shariah Governance Framework for Islamic Financial Institutions," BNM/RH/_012_3, Appendix 3: Sharĩah Committee's Report.

41. Hence, not everything is needed as long as it fulfils the basic disclosure and transparency requirement. But how the audit is conducted is not reported. Some banks' processes are too simplistic, raising transparency and proper governance issues.

42. Sheila Ainon Yussof and Omaima Khattab, "Selected Shariah Committee Reports in Malaysia: A Critical Appraisal," an INCEIF working paper for a PhD programme, 2009.

43. Ibid.

44. Ibid.

45. Global Arbitration Review online news, 17 Sept 2012, available online at http://www. globalarbitrationreview.com

46. Currently IFIs adopt a combination of international standards such as the AAOIFI, IFSB and MASB (local accounting standards).

47. As prescribed or defined under the CBM-SGF.

48. Joseph Eby Ruin, Internal Auditing: Supporting Risk Management, Fraud Awareness Management and Corporate Governance (Selangor: Leeds Publications, 2009, $2^{\text {nd }}$ ed.). 